НАУКОВИЙ ВІСНИК

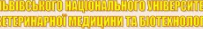

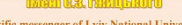

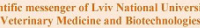

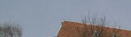
IM The СЕРАя: ХАРчові технологі Том 22 № 94 2020
Науковий вісник Дьвівського національного університету ветеринарної медицини та біотехнодогій імені С.3. Гжицького. Серія: Харчові технології

\section{Scientific Messenger of Lviv National University} of Veterinary Medicine and Biotechnologies.

Series: Food Technologies https://nvlvet.com.ua/index.php/food

UDC 664.8/.9:639.21:663.05

\title{
Improvement of technology of preserves from freshwater fish species
}

\author{
N. Golembovskaya \\ National University of Life and Environmental Sciences of Ukraine, Kyiv, Ukraine
}

Article info

Received 02.09.2020 Received in revised form 05.10 .2020

Accepted 06.10.2020

National University of Life and Environmental Sciences of Ukraine, Heroyiv Oborony Str., 15 , Kyiv, 03041, Ukraine. Tel.: +38-096-206-62-76 E-mail: natashagolembovska@gmail.com
Golembovskaya, N. (2020). Improvement of technology of preserves from freshwater fish species. Scientific Messenger of Lviv National University of Veterinary Medicine and Biotechnologies. Series: Food Technologies, 22(94), 27-31. doi: 10.32718/nvlvet-f9406

Changes in the structure of the fishery, the general trend of decreasing catches of traditional marine fish species, increasing the number of freshwater fish as aquaculture facilities necessitates the improvement of complex technologies for processing raw materials and expanding the range of food products from freshwater fish. One of the promising areas for solving these problems is the development of technology for preserves from freshwater fish and based on the principles of food combinatorics by enriching them with plant ingredients. The use of spicy-aromatic roots in the future is one of the priority areas of research. Substantiated and developed is of technology of freshwater fish preserves of increased biological value using spice-aromatic roots (parsley, ginger and horseradish), which solves the problem of production of optimized foodstuff according to the nutritive and biological value indicators. The necessity of using freshwater fish and aromatic roots in technology of preserves is grounded. Based on organoleptic analysis the compatibility of freshwater fish and spice-aromatic roots as part of preserves is determined. The results of studies of the chemical, fatty acid, amino acid and mineral composition of preserves and the assessment of their safety are presented. The preserves made modified by vegetative ingredient had the plastic and dense consistency on their cut. The positive results of their organoleptic analysis evidenced expediency of adding of proposed vegetative ingredient to fish. The conditions of preprocessing of salted semi-finished product with the aim of its further maturation as part of preserves is theoretically grounded and experimentally confirmed. The expediency of combining a freshwater fish with plant material to expand the range of biologically valuable food products is presented in the article. The proposed formulations of fish-based preserves products would permit to spread the assortment of dietetic products. The second positive effect of application vegetative raw materials in minced fish masses is finding one of more method of reprocessing the freshwater fish. The $R \& D$ work we performed would be continued and should include the stage of development and optimization the technologies of producing the fish products modified by vegetative raw.

Key words: freshwater fish preserves, spice-aromatic roots, biological value of proteins, biological effectiveness of lipids, structural and mechanical indicators.

\section{Удосконалення технології пресервів з прісноводних видів риб}

\author{
Н. В. Голембовська
}

Національний університет біоресурсів та природокористування Украӥни, м. Київ, Україна

\footnotetext{
Зміна структури промислу, загальна тенденція зниження обсягів вилову традиційних видів морських риб, збільиення кількості прісноводних риб як об'єктів аквакультури викликає необхідність удосконалення комплексних технологій переробки сировини та розиирення асортименту харчової продукиії із прісноводних риб. Одним із перспективних напрямів вирішення цих проблем є розробка технології пресервів із прісноводних риб на основі принципів харчової комбінаторики шляхом їх збагачення рослинними інгредієнтами. Використання пряно-ароматичних коренеплодів у подальшому є одним з пріоритетних напрямів досліджень. Обірунтовано та розроблено технології пресервів з прісноводних риб підвищеної біологічної иінності з використанням пряноароматичних коренеплодів (петрушки, імбиру та хрону), щзо вирімує проблему виробництва оптимізованих за показниками харчової та біологічної иінності продуктів харчування. Обірунтовано дочільність використання прісноводних риб і пряно-ароматичних коренеплодів у технологї пресервів. На основі органолептичного аналізу визначено сумісність прісноводної риби та пряноароматичних коренеплодів у складі пресервів. Наведено результати досліджень хімічного, жирно-кислотного, амінокислотного
} 
та мінерального складу пресервів та оичінка їхньої безпеки. Пресерви, зроблені з рослинними інгредієнтами, мали пластичну і щчільну консистенцію на розрізі. Позитивні результати органолептичного аналізу засвідчили доцільність додавання пропонованого рослинного інгредієнта до розмеленої маси риби. Теоретично обгрунтовані та експериментально підтверджені умови попередньої обробки солоного напівфабрикату з метою його подальшого дозрівання у складі пресервів. У статті обтрунтовано доцільність поєднання прісноводної риби з рослинним матеріалом для розиирення асортименту біологічно цінних харчових продуктів. Запропоновані рецептури рибних пресервів дозволяють розиирити асортимент дієтичних продуктів. Другим позитивним ефектом застосування рослинної сировини в подрібнених рибних масах є пошук ще одного зі способів переробки прісноводної риби. Роботи, які ми проводили, будуть продовжені та повинні включати стадію розробки й оптимізацї технологій виробництва рибних продуктів, модифікованих рослинною сировиною.

Ключові слова: пресерви із прісноводної риби, пряно-ароматичні коренеплоди, біологічна ияінність білків, біологічна ефективність ліпідів, структурно-механічні показники.

\section{Вступ}

Актуальною проблемою сьогодення є забезпечення населення високоякісними продуктами харчування підвищеної харчової та біологічної цінності. Обумовлено це порушенням харчового статусу, недостачею цілої низки незамінних факторів харчування. У зв'язку з цим все більшого значення набуває концепція створення нових, збалансованих за хімічним складом, збагачених функціональними компонентами харчових продуктів і забезпечення їхньої збереженості, безпечності після технологічної обробки, а також в процесі зберігання (Golembovskaya, 2018; 2019).

Сучасний стан харчування населення України потребує розроблення та впровадження технологій продуктів на основі натуральної сировини і прогнозованого складу, тому що представлений продуктами, які не забезпечують потреби людини в основних факторах харчування. В Україні відбувається нарощування обсягів вирощування та промислу прісноводних об'єктів, асортимент продукції яких обмежений живою та охолодженою рибою. Органолептичні показники прісноводної риби та їі харчова цінність потребують удосконалення технологій іiі переробки за рахунок комбінування з рослинною сировиною.

Системних досліджень у галузі активування процесів дозрівання прісноводних риб у складі пресервів не проводилось. Таким чином, розроблення технології пресервів із прісноводних риб та пряно-ароматичних коренеплодів $\epsilon$ актуальною проблемою, вирішення якої буде сприяти виробництву якісних та безпечних біологічно цінних риборослинних продуктів із вітчизняної сировини та розширення асортименту продуктів з використанням прісноводної риби.

Таким чином, зміна структури промислу, загальна тенденція зниження обсягів вилову традиційних видів морських риб, збільшення кількості прісноводних риб як об'єктів аквакультури викликає необхідність удосконалення комплексних технологій переробки сировини та розширення асортименту харчової продукції 3 прісноводних риб. Одним із перспективних напрямів вирішення цих проблем $є$ розробка технології пресервів із прісноводних риб на основі принципів харчової комбінаторики шляхом їхнього збагачення рослинними інгредієнтами. Використання пряно-ароматичних коренеплодів у подальшому є одним 3 пріоритетних напрямів досліджень.

Мета досліджень: розробити науковообгрунтовану технологію пресервів із прісноводної риби з використанням пряно-ароматичних коренепло- дів та розширення асортименту рибної продукції підвищеної біологічної цінності.

\section{Матеріал і методи досліджень}

Дослідження проводили з використанням такої сировини: риба жива весняного та осіннього вилову (короп) згідно з ДСТУ 2284 (DSTU 2284-93, 1995), вирощена у водосховищах ПАТ “Черкасирибгосп”; сіль кухонна згідно з ДСТУ 3583 (DSTU 3583-97, 1997); перець духмяний мелений згідно 3 ISO 973:1999 (ISO 973:1999, 1999); перець чорний мелений згідно з ГОСТ 29050 (GOST 29050-91, 1993); гвоздика згідно з ДСТУ ISO 2254:2008 (DSTU ISO 2254:2008, 2008); олія соняшникова згідно 3 ДСТУ 4492:2005 (DSTU 4492:2005, 2007); лавровий лист згідно з ГОСТ 17594 (GOST 17594-81, 1981); корінь петрушки (Petroselinum crispum) згідно 3 ДСТУ 343-91 (DSTU 343-91, 1992); корінь імбиру (Zingiber officinale) згідно з ДСТУ ISO 1003:2005 (DSTU ISO 1003:2005, 2007); корінь хрону (Armoracia rusticana) згідно з ДСТУ 294-91 (DSTU 294-91, 1992) 3 фермерських угідь Черкаської та Київської областей; оцет столовий згідно з ДСТУ 2450:2006 (DSTU 2450:2006, 2007); олія лляна згідно 3 ТУ У 15.414235416-001:2010 (TU U 15.4-14235416-001:2010, 2010).

Коропа розбирали на філе, яке солили тузлучним посолом до досягнення в ньому 5 \% солі за кімнатної температури протягом 24 годин. Потім філе порціонували на шматочки і закладали в поліетиленові банки 3 додаванням рослинної сировини (петрушки, імбиру, хріну).

Рецептури пресервів контрольних зразків складалися 3 м'яса коропа $-75 \%$ і заливки $-25 \%$. Зразки пресервів зберігали в пластикових контейнерах місткістю $200 \mathrm{~cm}^{3}$ за температурного режиму від 0 до $+4{ }^{\circ} \mathrm{C}$.

\section{Результати та їх обговорення}

Результати досліджень хімічного складу пресервів iз коропа та пряно-ароматичних коренеплодів наведені у таблиці 1.

Варто звернути увагу на те, що за мінеральним складом дослідні зразки відрізняються від контролю, що зумовлено вмістом мінеральних речовин у рослинних добавках (імбирі, хріні, петрушці), які в комплексі з рибною сировиною сприяють збагаченню пресервів. 
Жирнокислотний склад визначали в пресервах із використанням соняшникової олії і суміші соняшникової олії із лляною у співвідношенні 1:1. Жирнокис- лотний склад пресервів із використанням соняшникової олії наведений у таблиці 2.

Таблиця 1

Характеристика хімічного складу рибних пресервів $(\mathrm{n}=5, \mathrm{P} \leq 0,05)$

\begin{tabular}{lccccc}
\hline \multirow{2}{*}{ Зразок пресервів } & \multicolumn{5}{c}{ Масова частка, \% } \\
\cline { 2 - 6 } & вологи & білка & жиру & мінеральних речовин & клітковини \\
\hline Контроль & $70,49 \pm 1,88$ & $11,85 \pm 0,73$ & $9,36 \pm 0,65$ & $8,29 \pm 0,61$ & - \\
Пресерви з імбиром & $66,90 \pm 1,47$ & $11,93 \pm 0,74$ & $10,61 \pm 0,98$ & $9,55 \pm 0,23$ & $0,03 \pm 0,03$ \\
Пресерви з хроном & $65,61 \pm 1,78$ & $11,88 \pm 0,81$ & $11,99 \pm 1,05$ & $9,93 \pm 0,41$ & $0,05 \pm 0,03$ \\
Пресерви з петрушкою & $67,65 \pm 1,69$ & $11,68 \pm 0,31$ & $10,01 \pm 0,75$ & $10,15 \pm 0,66$ & $0,14 \pm 0,03$ \\
\hline
\end{tabular}

Таблиця 2

Жирнокислотний склад ліпідів пресервів із коропа i пряно-ароматичної сировини 3 використанням соняшникової олії

\begin{tabular}{|c|c|c|c|c|c|c|}
\hline \multirow[b]{2}{*}{ Жирні кислоти } & \multirow{2}{*}{$\begin{array}{l}\text { Код } \\
\text { ЖК }\end{array}$} & \multicolumn{4}{|c|}{ Вміст жирних кислот, \% від загальної їх кількості } & \multirow{2}{*}{$\begin{array}{c}\text { Рекомендована } \\
\text { кількість, г/добу } \\
\text { (Onishhenko, 2004) }\end{array}$} \\
\hline & & Контроль & $\begin{array}{l}\text { Пресерви } 3 \\
\text { імбиром }\end{array}$ & $\begin{array}{c}\text { Пресерви } 3 \\
\text { хріном }\end{array}$ & $\begin{array}{l}\text { Пресерви } 3 \\
\text { петрушкою }\end{array}$ & \\
\hline Насичені (НЖК), в т. ч. & & 24,80 & 29,92 & 30,78 & 29,93 & 25 \\
\hline мірістинова & 14:0 & 0,09 & 0,12 & 1,07 & 0,08 & \\
\hline пальмітинова & $16: 0$ & 20,52 & 25,63 & 25,44 & 25,59 & \\
\hline стеаринова & 18:0 & 3,64 & 3,59 & 3,62 & 3,57 & \\
\hline арахінова & 20:0 & 0,14 & 0,14 & 0,18 & 0,15 & \\
\hline нонадеканова & 19:0 & 0,41 & 0,45 & 0,47 & 0,54 & \\
\hline $\begin{array}{l}\text { Мононенасичені } \\
\text { (МНЖК), в Т. ч. }\end{array}$ & & 33,14 & 38,05 & 38,13 & 38,17 & 30 \\
\hline пальмітоолеїнова & $16: 1$ & 5,10 & 5,09 & 5,11 & 5,12 & \\
\hline$\omega 9$ олеїнова & $18: 1$ & 15,85 & 20,79 & 20,85 & 20,88 & \\
\hline$\omega_{9}$ елаїдинова & $18: 1$ & 12,14 & 12,15 & 12,15 & 12,17 & \\
\hline гадолеїнова & $20: 1$ & 0,06 & 0,02 & 0,02 & 0,02 & \\
\hline $\begin{array}{l}\text { Поліненасичені (ПНЖК), } \\
\text { В т. ч. }\end{array}$ & & 12,83 & 14,06 & 13,16 & 14,12 & 11 \\
\hline ліноленова $\omega_{3}$ & $18: 2$ & 6,09 & 7,15 & 6,15 & 7,17 & \\
\hline лінолева $\omega_{6}$ & $18: 3$ & 6,09 & 6,26 & 6,30 & 6,30 & \\
\hline ейкозадіснова & $20: 2$ & 0,64 & 0,65 & 0,71 & 0,65 & \\
\hline Не ідентифіковані & & 29,23 & 17,98 & 17,93 & 17,79 & \\
\hline
\end{tabular}

\section{Таблиця 3}

Жирнокислотний склад ліпідів пресервів 3 коропа та пряно-ароматичної сировини 3 використанням соняшникової та лляної олії

\begin{tabular}{|c|c|c|c|c|c|c|}
\hline \multirow[b]{2}{*}{ Жирні кислоти } & \multirow[b]{2}{*}{$\begin{array}{l}\text { Код } \\
\text { ЖК }\end{array}$} & \multicolumn{4}{|c|}{ Вміст жирних кислот, \% від загальної їх кількості } & \multirow{2}{*}{$\begin{array}{c}\text { Рекомендована } \\
\text { кількість, г/добу } \\
\text { (Tsypriian et al., 2007) }\end{array}$} \\
\hline & & контроль & $\begin{array}{c}\text { пресерви } \\
3 \text { імбиром }\end{array}$ & $\begin{array}{l}\text { пресерви } \\
\text { i3 хріном }\end{array}$ & $\begin{array}{c}\text { пресерви з пет- } \\
\text { рушкою }\end{array}$ & \\
\hline Насичені (НЖК), в т. ч. & & 24,80 & 10,05 & 10,09 & 10,82 & 25 \\
\hline тридеканова & $13: 0$ & - & 0,17 & 0,21 & 0,33 & \\
\hline пальмітинова & $16: 0$ & 20,52 & 5,70 & 5,71 & 6,43 & \\
\hline стеаринова & $18: 0$ & 3,64 & 3,88 & 3,88 & 3,85 & \\
\hline арахінова & $20: 0$ & 0,14 & 0,30 & 0,28 & 0,21 & \\
\hline нонадеканова & $19: 0$ & 0,41 & - & - & - & \\
\hline мірістинова & $14: 0$ & 0,09 & - & - & - & \\
\hline Мононенасичені (МНЖК), в т. ч. & & 33,14 & 22,37 & 22,13 & 22,18 & 30 \\
\hline пальмітоолеїнова & $16: 1$ & 5,10 & - & - & - & \\
\hline$\omega_{9}$ олеїнова & $18: 1$ & 15,85 & 22,37 & 22,13 & 22,18 & \\
\hline$\omega_{9}$ елаїдинова & $18: 1$ & 12,14 & - & - & - & \\
\hline гадолеїнова & $20: 1$ & 0,06 & - & - & - & \\
\hline Поліненасичені (ПНЖК), в т. ч. & & 12,83 & 67,33 & 67,51 & 66,76 & 11 \\
\hline ліноленова $\omega_{3}$ & $18: 2$ & 6,09 & 59,97 & 60,09 & 59,58 & \\
\hline лінолева $\omega_{6}$ & $18: 3$ & 6,09 & 6,46 & 6,51 & 6,38 & \\
\hline ліноленова $\omega 6$ & $18: 3$ & - & 0,29 & 0,26 & 0,22 & \\
\hline арахідонова & $20: 4$ & - & 0,61 & 0,65 & 0,58 & \\
\hline ейкозадієнова & $20: 2$ & 0,64 & - & - & - & \\
\hline Не ідентифіковані & & 29,23 & 0,25 & $\mathbf{0 , 2 7}$ & 0,24 & \\
\hline
\end{tabular}


За експериментальними даними, вміст усіх груп ЖК у досліджуваних нами пресервах перевищує рекомендовану кількість виключно контрольний, в якому сума насичених кислот наближається до рекомендованої кількості. Серед насичених кислот домінуючою $є$ пальмітинова, вміст якої в експериментальних зразках із різними пряно-ароматичними коренеплодами перевищує контрольний зразок на 5 \%.

Жирнокислотний склад пресервів із використанням соняшникової і лляної олії наведений у таблиці 3.

Аналізуючи наведені дані таблиці 3, встановлено, що вміст насичених і мононенасичених ЖК порівняно 3 рекомендованою кількістю в дослідних зразках нижчий, але збагачення пресервів проходить за рахунок високого вмісту поліненасичених ЖК, а саме лінолевої кислоти, якою багата лляна олія.

Результати показників біологічної ефективності ліпідів пресервів із коропа і пряно-ароматичної сировини з використанням соняшникової олії та соняшниково-лляної олії наведені у таблиці 4.

Особливо варто наголосити на тому, що виявлений нами високий вміст жирних кислот родини $\omega_{3}$ в ліпідах пресервів свідчить про їхню високу біологічну ефективність.

Характеристика впливу пряно-ароматичних коренеплодів на мінеральний склад пресервів із прісноводної риби коропа наведена в таблиці 5 .

\section{Таблиця 4}

Показники біологічної ефективності ліпідів пресервів 3 коропа та пряно-ароматичної сировини 3 використанням соняшникової та лляної олії

\begin{tabular}{|c|c|c|c|c|}
\hline \multirow{2}{*}{ Ліпіди } & \multicolumn{4}{|c|}{ Співвідношення типів ЖК } \\
\hline & НЖК:МНЖК:ПНЖК & ПНЖК:НЖК & $\mathrm{C} 18: 2: \mathrm{C} 18: 1$ & $\omega_{6}: \omega_{3}$ \\
\hline \multicolumn{5}{|c|}{ із соняшниковою олією } \\
\hline Контроль & $1: 1,34: 0,52$ & $0,52: 1$ & $1: 2,60$ & $1: 1,00$ \\
\hline Пресерви з імбиром & $1: 1,27: 0,47$ & $0,47: 1$ & $1: 0,37$ & $1: 1,14$ \\
\hline Пресерви з хріном & $1: 1,24: 0,43$ & $0,43: 1$ & $1: 0,36$ & $1: 0,98$ \\
\hline Пресерви з петрушкою & $1: 1,28: 0,47$ & $0,47: 1$ & $1: 0,37$ & $1: 1,14$ \\
\hline \multicolumn{5}{|c|}{ із соняшниковою і лляною олією } \\
\hline Контроль & $1: 1,34: 0,52$ & $0,52: 1$ & $1: 2,60$ & $1: 1,00$ \\
\hline Пресерви з імбиром & $1: 2,23: 6,69$ & $6,69: 1$ & $1: 0,37$ & $1: 9,28$ \\
\hline Пресерви з хріном & $1: 2,19: 6,69$ & $6,69: 1$ & $1: 0,36$ & $1: 9,23$ \\
\hline Пресерви з петрушкою & $1: 2,05: 6,17$ & $6,17: 1$ & $1: 0,37$ & $1: 9,35$ \\
\hline
\end{tabular}

\section{Таблиця 5}

Вплив додавання пряно-ароматичних коренеплодів на мінеральний склад пресервів 3 прісноводної риби коропа, мг/100 г $(\mathrm{n}=5, \mathrm{P} \leq 0,05)$

\begin{tabular}{lrrrrr}
\hline \multirow{2}{*}{$\begin{array}{l}\text { Мінеральний } \\
\text { елемент }\end{array}$} & \multicolumn{4}{c}{ Досліджувані пресерви: } & 10 \% від адекватної добо- \\
\cline { 2 - 4 } контроль & з імбиром & із хріном & з петрушкоютреби споживання \\
\hline Калій & $83,51 \pm 2,11$ & $93,89 \pm 2,02$ & $108,87 \pm 3,09$ & $97,21 \pm 2,43$ & 250 \\
Кальцій & $15,43 \pm 0,69$ & $21,69 \pm 0,61$ & $21,81 \pm 1,06$ & $28,99 \pm 1,02$ & 125 \\
Сірка & $19,11 \pm 0,80$ & $22,73 \pm 0,30$ & $26,77 \pm 1,15$ & $20,23 \pm 1,13$ & 1,0 \\
Залізо & $0,15 \pm 0,02$ & $0,59 \pm 0,03$ & $0,22 \pm 0,03$ & $0,26 \pm 0,03$ & 1,5 \\
Марганець & - & $0,17 \pm 0,02$ & $0,01 \pm 0,005$ & $0,03 \pm 0,006$ & 0,2 \\
\hline
\end{tabular}

Виходячи з цих результатів, в пресервах із пряноароматичними коренеплодами порівняно 3 контрольним зразком суттєво підвищений рівень усіх мінеральних елементів, що свідчить про доцільність внесення пряно-ароматичних коренеплодів у даний продукт 3 метою збагачення його важливими мінеральними елементами для отримання більш цінного і корисного продукту харчування.

\section{Висновки}

1. Проведені дослідження щодо хімічного складу пресервів дали позитивні результати і засвідчили, що 3 додаванням пряно-ароматичних коренеплодів збільшується вміст мінеральних речовин порівняно 3 контрольним зразком.
2. Біологічна ефективність жирнокислотного складу пресервів 3 коропа обумовлена збільшенням кількості поліненасичених жирних кислот, а саме лінолевої кислоти $\omega_{6}$, яка була внесена 3 додаванням до м'яса риби лляної олії та порівняно 3 добовою потребою перевищує рекомендований вміст.

3. Оскільки, пряно-ароматичні коренеплоди містять велику кількість поживних речовин, таких як амінокислоти (аргінін, гістидин, лізин, аланін), вуглеводи (глюкоза, галактоза, арабіноза) та мінеральні речовини (калій, кальцій, фосфор, натрій, залізо, магній), то поєднання обраних інгредієнтів у пресервах дає змогу сформувати продукт харчування з високими органолептичними властивостями та функціонального призначення.

Перспективи подальших досліджень. Отримані позитивні дослідження свідчать про доцільність ви- 
вчення даної технології та потребують подальших розробок.

\section{References}

DSTU 2284-93 (1995). Ryba zhyva. Zahalni tekhnichni umovy. Diie z 1995.01.01. K.: Vyd-vo standartiv (in Ukrainian).

DSTU 2450:2006 (2007). Uksusy iz pishhevogo syr'ja. Obshhie tehnicheskie uslovija. Dejstvuet s 2007.07.01. Derzh. kom. stand. metr. ta sert. Ukrainy (in Russian).

DSTU 294-91 (1992). Hren-koren' svezhij. Tehnicheskie uslovija. Dejstvuet s 1992.07.01. Derzh. kom. stand. metr. ta sert. Urainy (in Russian).

DSTU 343-91 (1992). Petrushka kornevaja svezhaja. Tehnicheskie uslovija. Dejstvuet s 1992.07.01. Derzhspozhivstandart Urainy (in Russian).

DSTU 3583-97 (1997). Sil kukhonna. Zahalni tekhnichni umovy. Diie z 1997.01.07. K.: Vyd-vo standartiv. URL: http://www.salt.kh.ua/?page id=555 (in Ukrainian).

DSTU 4492:2005 (2007). Oliia soniashnykova. Zahalni tekhnichni umovy. Diie z 2007.01.01. K.: Vyd-vo standartiv. URL: http://august.in.ua/ru/vocabulary/dstu44922005-oliya-sonyashnikova-tehnichni-umovi (in Ukrainian).

DSTU ISO 1003:2005 (2007). Prjanosti i pripravy. Imbir' kornevishhami, kusochkami ili molotyj. Tehnicheskie uslovija (ISO 1003:1980, IDT). Dejstvuet s 2007.07.01. Gospotrebstandart (in Russian).

DSTU ISO 2254:2008 (2008). Gvozdika celaja i molotaja (poroshkoobraz.). Tehnicheskie uslovija. Dejstvuet $\mathrm{s}$ 2010.01.01. K.: Gospotrebstandart (in Russian).

Golembovskaya, N. (2018). Research on changes of the quality indicators of semi-finished of dietary minced products during their storage. Scientific Messenger of Lviv National University of Veterinary Medicine and Biotechnologies, 20(90), 17-21. doi: 10.32718/nvlvet9004.

Golembovskaya, N. (2019). Usage of chia seeds in the composition of dietary semi-finished minced products. Scientific Messenger of Lviv National University of Veterinary Medicine and Biotechnologies. Series: Food Technologies, 21(92), 19-22. doi: 10.32718/nvlvetf9204.

GOST 17594-81 (1981). List lavrovyj suhoj. Tehnicheskie uslovija. Dejstvuet s 1982.06.30. M.: Izd-vo standartov. URL: http://docs.cntd.ru/document/1200024563 (in Russian).

GOST 29050-91 (1993). Prjanosti. Perec chernyj i belyj. Tehnicheskie uslovija. Dejstvuet s 1993.01.01. M.: Izdvo standartov. URL: http://docs.cntd.ru/document/ 1200022584 (in Russian).

ISO 973:1999 (1999). Perec dushistyj [Pimenta dioica (L.) Merr.] v zernah ili molotyj. Tehnicheskie uslovija. Dejstvuet s 1999.10.01. M.: Izd-vo standartov (in Russian).

Onishhenko, G. G. (2004). Racional'noe pitanie. Rekomenduemye urovni potreblenija pishhevyh i biolo-gicheski aktivnyh veshhestv. URL: http://www.consultpharma.ru/index.php/ru/documents /fs/615-mr2-3-1-19150-04 (in Russian).

Tsypriian, V. I., Manasar, Sh. T., \& Slobodkin, V. Sh. (2007). Hihiiena kharchuvannia z osnovamy nutrytsiolohii. pidruch. u 2-kh kn. K.: Medytsyna (in Ukrainian).

TU U 15.4-14235416-001:2010 (2010). Oliia liana. Tekhnichni umovy. Diie z 2010. K.: Derzhstandart Ukrainy (in Ukrainian). 